\title{
GRINDING AND POLISHING MATERIALS.
}

\author{
By F. J. KA'T.
}

Investigations by the United States Geological Survey show that domestic resources can adequately supply domestic demands for all materials used for grinding and polishing except diamond dust and bort. The American industries requiring millstones, grindstones, pulpstones, oil stones, whetstones, scythestones, corundum, garnet, silica, feldspar, diatomaceous earth, and tripoli have long been independent of foreign supplies, and the developed domestic sources of supply are capable of greatly increased production. The imports of these materials have been small in comparison with domestic production and have very probably been fostered only by a natural preference and conservatism in favor of articles that had long been used before the American supplies came into the market. This conservatism will be forcibly broken down in the event of further difficulty of intercourse with Europe, and the domestic or Canadian materials will be satisfactory in quality and ample in quantity to supply all our needs.

On the other hand, American emery seems to be inferior to and unable to supplant the emery from Naxos, Greece, imports of which have been very largely shut out. Artificial carbide and aluminum oxide abrasives can be substituted, but some manufacturers, particularly lens grinders, seem to be reluctant to make a change, probably because it would involve changes in technique. Necessity must overcome such reluctance.

Corundum for a number of years has been supplanted by the artificial abrasives. Very recently, however, there has been a small revival in corundum mining. In the southern Appalachian and Piedmont provinces and elsewhere there are deposits of natural corundum which are well known and abundant, ${ }^{1}$ and these may be worked whenever conditions warrant. It seems that about 3 to 5 per cent of the bauxite produced in the United States has been used in the manufacture of abrasive materials. A heavy increase in the demand for metallic aluminum may divert to aluminum extraction the bauxite

1 See Pratt, J. H., Corundum and its occurrence and distribution in the United States: U. S. Geol. Survey Bull. 269, 1906. 
ores that have been used in the manufacture of artificial abrasives. However, bauxite ores of lower grade than those in use are available for excess demands, and it does not seem probable that the manufacture of artificial aluminum oxide abrasives would be inhibited by an unusual demand for metallic aluminum. If it is, dependence will have to be placed on natural corundum for a very large proportion of the abrasive materials used in the metal trades, and such dependence will undoubtedly involve increased costs and difficulties of readjustment.

No domestic source of satisfactory lump pumice has been exploited commercially. Deposits of such material are known in Utah and southern California and in the Crater Lake region of Oregon. Probably there are many others in the Western States, but no information is at hand concerning the quantity and quality of such material, and doubtless much of it is far from transportation routes. Fortunately little of the imported pumice is used in the lump form. The ground or powdered material is chiefly in demand, and this can be satisfactorily and wholly supplied by the pumice dust or so-called volcanic ash that is extraordinarily abundant in the central part of the United States. This pumice dust has been adequately meeting the situation created by interference with shipping from Mediterranean ports.

The country remains dependent on foreign sources for diamond dust and bort, imports of which in the last three years have been about 25 per cent less than the average during the previous three years.

Up to 1914 the United States had been dependent on Europe, chieffy Denmark and France, for its supply of flint pebbles, which were used in grinding mills and were also crushed and ground for use in the body of ceramic wares. "Flint" blocks cut to specified dimensions for use in lining tube mills had also been supplied to American trade from foreign sources only. Late in 1914 and in 1915 the prices of these imported materials advanced in anticipation of difficulty in obtaining adequate supplies. This condition stimulated search for American flints or fint substitutes and led to suggestions by the United States Geological Survey as to possible sources of domestic supply. ${ }^{1}$ Since 1914 domestic substitutes for flint pebbles have been introduced, and there is at present every promise of complete independence of European supplies. The pottery industry does not need ground flint, inasmuch as pure silica from other sources is equally satisfactory and has long been used by American potters. American sources of silica, such as clean sands, sandstones, quartzites, and vein and pegmatite quartz, are practically unlimited and widely distributed, so that they are readily available in all markets. The pottery

2 Our mineral reserves: U. S. Geol. Survey Bull. 599, pp. 38-40, 1914. 
industry, however, is in need of siliceous pebbles for grinding quartz and feldspar in tube mills. Substitutes that contain even small quan, tities of iron can not be used. This need may be supplied from the gravel deposits that are particularly abundant in the Gulf States and Arkansas. Gravel composed of flint or chert pebbles has been noted in many places, and some of the gravel deposits in Arkansas contain abundant novaculite pebbles, which will be satisfactory substitutes for the imported flint pebbles. No effort has been made, however, to develop these deposits, partly because the imports of Danish or French pebbles have not yet been short enough or the foreign pebbles have not yet increased enough in price to force the development of domestic supplies.

Metallurgic plants and cement mills have used a far larger quantity of flint pebbles than the pottery industry. The pure silica pebble is not required for them, the only essentials being toughness and hardness. For these purposes there are large quantities of suitable granite and porphyry pebbles in many localities along the New England coast which have not yet been drawn upon. During 1916 approximately 6,000 tons of pebbles were shipped from the coast of San Diego County, Cal., to metallurgic plants and cement mills, where they have proved to be entirely satisfactory and have cost far less than imported flint pebbles. Some grinding plants are using lumps of hard ore or other rock to supplant either in part or wholly the pebbles formerly used. Some of the Nevada gold mills are being supplied with artificially rounded blocks of chalcedonized rhyolite. Finally the use of steel and steel alloy balls, instead of pebbles, is on the increase. It is thus evident that American cement and metallurgic industries could do entirely without a supply of foreign flint pebbles.

Dimension blocks cut from quartzites in Florida, Tennessee, and Iowa have appeared on the market during the last two years and seem to be satisfactorily supplanting foreign flint lining. 
